\title{
The role of physics in radioecology and radiotoxicology
}

\author{
Branko Petrinec, Marko Šoštarić, and Dinko Babić \\ Institute for Medical Research and Occupational Health, Zagreb, Croatia
}

[Received in November 2018; Similarity Check in December 2018; Accepted in February 2019]

\begin{abstract}
This article gives an overview of physical concepts important for radioecology and radiotoxicology to help bridge a gap between non-physicists in these scientific disciplines and the intricate language of physics. Relying on description and only as much mathematics as necessary, we discuss concepts ranging from fundamental natural forces to applications of physical modelling in phenomenological studies. We first explain why some atomic nuclei are unstable and therefore transmute. Then we address interactions of ionising radiation with matter, which is the foundation of both radioecology and radiotoxicology. We continue with relevant naturally occurring and anthropogenic radionuclides and their properties, abundance in the environment, and toxicity for the humans and biota. Every radioecological or radiotoxicological assessment should take into account combined effects of the biological and physical half-lives of a radionuclide. We also outline the basic principles of physical modelling commonly used to study health effects of exposure to ionising radiation, as it is applicable to every source of radiation but what changes are statistical weighting factors, which depend on the type of radiation and exposed tissue. Typical exposure doses for stochastic and deterministic health effects are discussed, as well as controversies related to the linear no-threshold hypothesis at very low doses.
\end{abstract}

KEY WORDS: ecology; radionuclides; ionising radiation; toxicity

Radioactivity is everywhere around us. We cannot detect it by our senses but we have been exposed to it during our evolution no less than to other natural phenomena. This raises a number of questions on its role in the environment, which are being addressed by a scientific discipline called radioecology. In addition, exposure to nuclear radiation from natural and artificial sources implies a necessity to investigate the related health effects, and these issues are addressed by radiotoxicology. Studies of different aspects of radioactivity are no longer in the domain of physics alone, since radioecology and radiotoxicology also involve a wide spectrum of sciences ranging from chemistry to medicine. However, the concepts of nuclear quantum phenomena related to radioactivity generally still elude non-physicists. The goal of this review is therefore to help bridge this gap by summarising physical models of relevance to radioecology and radiotoxicology and help researchers from different fields to understand the microscopic phenomena that underlie macroscopic manifestations of ionising radiation.

Since the discovery of radioactivity by Henry Becquerel in 1896 (1), nuclear physics has explained a vast number of intricate interactions and processes involving nuclear forces. For the last few decades the interest has shifted towards processes which occur at energies that are much higher than those typical of an atomic nucleus. In this sense, one could say that the physics of radioactive decay is a

Corresponding author: Dinko Babić, Institute for Medical Research and Occupational Health, Ksaverska cesta 2, HR-10000 Zagreb

E-mail:dbabic@imi.hr relatively old science, but this does not hold true for radioactivity-related ecological or toxicological issues. For example, the conversion of an atomic nucleus into another, which is termed nuclear transmutation, has a twofold effect in a tissue. First, $\gamma$ photons and/or charged $\alpha$ or $\beta$ particles are emitted into a complex organic environment where they ionise atoms and molecules, change their chemical properties, and consequently the reactions they undergo. This, in turn, alters biological functions. Second, the emitting atom mutates into another one and changes its own chemical properties, which affects biological functions at the place of emission. On a larger scale, in ecosystems, propagation pathways of radionuclides through different media are of primary importance, but the exposure of humans and biota to radioactive sources in the environment brings us back to the effects of radioactivity at a molecular level. The above examples demonstrate how much the physics of radioactivity is intertwined with other sciences involved in radioecology and radiotoxicology and how this seemingly old branch of physics has now taken a new role in interdisciplinary research.

We shall first address the properties of nucleons - the proton (p) and the neutron (n) - and the forces which underlie their interactions in a nucleus. This will be followed by a discussion of the exponential law of radioactive decay, which always holds true, irrespective of the type of transmutation. We shall also give an overview of transmutations and the consequent radiation emissions. This part will be concluded by an outline of interactions between nuclear radiation and matter, which is a key to understanding the general effects of ionising radiation. 
The above considerations will be extended to radioecology, where physics provides a link between radionuclides in the environment and their sources. This takes into account not only the origin of radionuclides (primordial, decay chains, cosmogenic, anthropogenic) but also other properties which determine their distribution in the environment.

As physics also plays an important role in radiotoxicology, we shall review standard models accounting for radiation doses received via external and internal exposure. These models include the biological half-life of a radionuclide inside the body (not only its physical half-life) and the type of radiation, and also take into account that different tissues respond to exposure differently. Medical procedures (diagnostic and therapeutic) involving radionuclides and other sources of ionising radiation employ the same concepts, which represents another extension of physics into other areas of science and technology.

\section{THE PHENOMENON OF RADIOACTIVITY}

\section{Basic concepts}

There are four fundamental forces known to humankind, and they are responsible for all processes and interactions that our science has encountered (2). The first is the strong nuclear force (SNF), which underlies the attraction between nucleons and does not depend on whether the nucleons are $\mathrm{p}$ or $\mathrm{n}$. This is the strongest force known to us, but it acts over very short distances, so that nucleons must virtually touch each other in order to bind together. Charged particles interact via the electromagnetic force (EMF) - the second of the fundamental forces - which can be either attractive (for unlike charges) or repulsive (for like charges). Since the proton carries a single positive charge, the $\mathrm{p}-\mathrm{p}$ repulsion in a nucleus acts against the attractive SNF. At the same distance, the SNF is about hundred times stronger than the EMF, but the range of the latter one is infinite. Not only is the EMF important in the atomic nucleus, but is also responsible for chemical bonding that occurs at the level of valence electrons. The third of the fundamental forces is the weak nuclear force (WNF) which is responsible for beta $(\beta)$ decay and, therefore, important in nuclear transmutations. It is much weaker than the SNF $\left(10^{3}-10^{13}\right.$ times, estimates vary) and also short-ranged. The fourth of the fundamental forces is the gravitational force which has an infinite range but is very weak $\left(10^{35}-10^{42}\right.$ times weaker than the SNF) and therefore irrelevant in microscopic interactions.

The interplay between the SNF, EMF, and WNF determines the total energy of a nucleus and, consequently, its stability. The key factor is the number of $\mathrm{n}$ relative to that of $\mathrm{p}$. A nucleus which has a mass number $Y$, comprising $Z$ protons and $Y-Z$ neutrons, is stable against a transmutation only if $Z$ and $Y-Z$ are such that they lie within the so-called valley of stability where the ratios of $\mathrm{n}$ and $\mathrm{p}$ are balanced (3). Otherwise, the nucleus is unstable because it can transmute into a lower energy one. Unstable isotopes are termed radionuclides. For instance, ${ }^{206} \mathrm{~Pb},{ }^{207} \mathrm{~Pb}$, and ${ }^{208} \mathrm{~Pb}$ are stable whereas ${ }^{210} \mathrm{~Pb},{ }^{211} \mathrm{~Pb},{ }^{212} \mathrm{~Pb}$, and ${ }^{214} \mathrm{~Pb}$ are not; all of them are naturally occurring, but the latter ones are radionuclides which undergo transmutations until reaching the valley of stability. There are numerous nuclear transmutations, which will be addressed later, but all of them follow a remarkably simple statistics known as the law of radioactive decay, as follows. The number $N$ of radioactive nuclei is reduced in time $t$ according to

$N(t)=N_{0} e^{-\lambda t}$,

where $\lambda$ is the decay constant. At $t=T_{1 / 2}=\ln 2 / \lambda$, the number of nuclei is reduced to $N_{0} / 2$, and $T_{1 / 2}$ (called halflife) is traditionally used as a time scale for the decay of a radionuclide. In radioactivity studies, the most important measurable quantity is radionuclide activity $A$ which is defined as

$A(t)=-d N / d t=\lambda N_{0} e^{-\lambda t}=A_{0} e^{-\lambda t}=\lambda N(t)$.

The SI unit for $A$ is becquerel (Bq), and $1 \mathrm{~Bq}=1 \mathrm{~s}^{-1}$. When one wants to quantify the radioactivity of a given medium that comprises both stable isotopes and radionuclides, one uses activity concentration, that is, $A$ per unit of quantity (for instance, $\mathrm{Bq} \mathrm{kg}^{-1}$ or $\mathrm{Bq} \mathrm{m}^{-1}$ ).

It frequently happens that there is a cascade of transmutations instead of only one. In this case, for $k$ members of the cascade, the time dependence of the number of nuclei is given by $k$ coupled Bateman equations (4)

$d N_{1} / d t=-\lambda_{1} N_{1}, d N_{i} / d t=\lambda_{i-1} N_{i-1}-\lambda N_{i},(i=2, \ldots, k)$.

The first of the above equations describes the decay of a parent radionuclide, whereas the second accounts for the number of the nuclei of the $i^{\text {th }}$ radionuclide. $N_{i}(t)$ decreases due to own decay but also increases due to the decay of the previous radionuclide in the cascade. These cascades are usually termed decay chains; they are named after the parent radionuclide, and end with a stable nucleus with $\lambda_{k}=0$.

The above consideration explains how to quantify a source of nuclear radiation but it neither addresses the energy carried by the radiation nor its deposition in case of an interaction with matter. The total energy $E_{\mathrm{em}}$ emitted by a radioactive source is given by

$E_{\mathrm{em}}=t\left[\Sigma_{\alpha, j} A_{\alpha} \eta_{\alpha j} \varepsilon_{\alpha j}+\Sigma_{\beta, l} A_{\beta} \eta_{\beta l} \varepsilon_{\beta l}+\Sigma_{\gamma m} A_{\gamma} \eta_{\gamma m} \varepsilon_{\gamma m}\right]$

where $A_{\alpha}, A_{\beta}$, and $A_{\gamma}$ are activities resulting in emissions of $\alpha, \beta$, and $\gamma$ radiation, respectively, with indices $j, l$, and $m$ accounting for statistically distributed emissions (with energies $\varepsilon$ and the corresponding emission probabilities $\eta \leq 1$, which will be discussed in more detail later). For 
interactions between ionising radiation and matter it is important how much energy $E_{\mathrm{dep}} \leq E_{\mathrm{em}}$ is deposited by the radiation in a mass $M$, and the quantity that accounts for that is absorbed dose

$$
D=d E_{\mathrm{dep}} / d M
$$

It is also important at what rate is $E_{\text {dep }}$ deposited, as short-term and long-term exposures to the same amount of energy may have different effects on living organisms. Therefore, often it is the dose rate

$$
\dot{D}=d D / d t
$$

that is studied. The SI unit of $D$ is grey $\left(1 \mathrm{~Gy}=1 \mathrm{~J} \mathrm{~kg}^{-1}\right)$, and of $\dot{D}$, of course, Gy s ${ }^{-1}$. However, $D$ is in practice often expressed in Gy $\mathrm{h}^{-1}$.

Different tissues respond differently to the same type of radiation and amount of deposited energy. In order to account for that, the concept of equivalent dose $H$ has been introduced. $H$ is basically $D$ modified for specific interactions of different tissues with different types of radiation. Equations [5] and [6] apply to $H$ in the same way as they do to $D$, but the unit of $H$ is sievert $\left(1 \mathrm{~Sv}=1 \mathrm{~J} \mathrm{~kg}^{-1}\right)$. Although Gy and Sv are dimensionally the same, they have different meanings, since Sv takes into account biological effects and Gy does not.

The above concepts apply in every situation where radionuclides undergo transmutations and emit radiation and they are in fact sufficient for understanding the meaning of the result of a measurement relevant to radioecology and radiotoxicology. However, it is also often necessary to understand the mechanisms behind such results, which requires a deeper insight into the physics of radioactive decay.

\section{Nuclear transmutations and radiation emission}

Nuclear processes are governed by the laws of quantum physics; they obey the universal conservation laws and are affected by the Einstein's energy-mass equivalence. One should therefore address these three topics before turning to nuclear transmutations and radiation.

The first step is to clarify that there are three classes of particles of importance for the issues under discussion. This first of these are photons, massless quanta of electromagnetic radiation. This class includes $\gamma$ rays, whose energy ranges roughly from $10 \mathrm{keV}$ to a few $\mathrm{MeV}$, where $1 \mathrm{eV}=1.6 \times 10^{-19} \mathrm{~J}$ is the usual energy unit in microscopic processes. X-ray photons may have the same energies as $\gamma$ photons, but their source is different, as they originate in electromagnetic phenomena involving electrons outside the nucleus.

The second class of the particles of interest are leptons. These particles are affected by the WNF but do not interact via the SNF. They have antiparticles of the same mass and, if a lepton is charged, of the opposite charge. The electron $\mathrm{e}^{-}$and the positron $\mathrm{e}^{+}$are the best know examples of a lepton and its antiparticle, respectively. They are assigned a lepton number which equals +1 for leptons, -1 for their antiparticles, and 0 for non-leptons. Conservation of lepton number is one of the six fundamental conservation laws and must be satisfied in every process. For example, the equation of $\beta^{-}$ decay, i.e., of an $n$ becoming a $p$, is

$\mathrm{n} \rightarrow \mathrm{p}+\mathrm{e}^{-}+\overline{\mathrm{e}^{-}}$

where $\bar{v}_{\mathrm{e}}$ is the electron antineutrino, a very light, electrically neutral lepton and the antiparticle of the electron neutrino $v_{\mathrm{e}}$. The appearance of $\overline{\mathrm{e}}_{\mathrm{e}}$ is required because $\mathrm{e}^{-}$has a lepton number $+1, \mathrm{p}$ and $\mathrm{n}$ are not leptons and their lepton numbers are therefore zero, and a lepton antiparticle is required in Eq. [7] in order that the total lepton number remains zero after the n-to-p conversion. Another conservation law explains why $\mathrm{e}^{-}$and not $\mathrm{e}^{+}$appears on the right-hand side of Eq. [7], and this is conservation of electrical charge: as $n$ has no electrical charge, an opposite and exactly equal charge must cancel the positive charge of $\mathrm{p}$.

Finally, we ought to discuss baryons, i.e., particles that consist of quarks held together by the SNF. They are heavy particles, can be either electrically charged or neutral, have antiparticles, and, like leptons, are assigned a baryon number $(+1$ for particles, -1 for antiparticles, 0 for nonbaryons). The proton and the neutron belong to this class, both being composed of three quarks. There is also the law of conservation of baryon number, which is satisfied in Eq. [7], because both $n$ and $p$ have a baryon number +1 and the equation is balanced with regard to baryon number.

$\beta^{+}$decay, which is a p-to-n conversion, is a good example of the energy-mass equivalence that is often manifested in nuclear processes. An isolated $\mathrm{p}$ cannot become an isolated $n$ because of its slightly smaller mass; thus, $\beta^{+}$decay seems to be impossible. However, there are $\beta^{+}$decays in nature. For instance, ${ }^{23} \mathrm{Mg}$ transmutes to ${ }^{23} \mathrm{Na}$, which is accompanied by the emission of an $\mathrm{e}^{+}$and a $v_{\mathrm{e}}$ (which means that the lepton number, baryon number, and electrical charge are conserved). The process which allows for that to happen is the conversion of some of the nuclear mass in ${ }^{23} \mathrm{Na}$ into the nuclear binding energy according to $E=M c^{2}$, where $c$ is the speed of light. This apparently makes the resulting neutron lighter and enables the p-to-n conversion. In turn, the classical law of conservation of mass is actually just a manifestation of the fundamental law of conservation of energy.

The remaining topic that we ought to address is the quantum nature of the atomic nucleus. It turns out that energy levels in atomic nuclei are quantised, i.e., discrete. This is because the manifestations of the SNF are always quantum. What is important for this discussion is that a nucleus can be in an excited energy state and fall into a lower state not only by transmutation but also by emitting a $\gamma$ photon without changing either the total number or the 
type of its nucleons. This is similar to the emission of a photon when an electron in an atomic shell falls into a lower energy state, so that the total energy of the atom is reduced by this emission. In the case of nuclei, this often happens (but not always) after a transmutation has taken place, if the daughter nucleus is in an excited state and then relaxes until it reaches the lowest energy state by $\gamma$ emission(s). Therefore, a transmutation can occur with or without an emission of $\gamma$ radiation, depending on the nucleus.

While details of the outlined phenomena are generally complex, the above simplified discussion is sufficient to understand different types of nuclear transmutations and consequent emissions of radiation, at least qualitatively. It should also be noted that $v_{\mathrm{e}}$ and $\overline{v_{\mathrm{e}}}$ are of no interest regarding the ecological and toxicological effects of nuclear radiation, as they react with matter only weakly, by the short-ranged WNF. We shall therefore focus on the emission of $\gamma$ photons and $\alpha, \beta$, and $\beta^{+}$charged particles.

Transmutations that result in the emission of an $\alpha$ particle (which are the same as the ${ }^{4} \mathrm{He}$ nuclei, consisting od two $\mathrm{p}$ and two $\mathrm{n}$ and having a double positive charge) occur mainly for heavy nuclei $(Y>150)$ rich in protons (5). Energies of $\alpha$ particles are high (several $\mathrm{MeV})$, discrete, and characteristic of a given nucleus $(5,6)$. Therefore, the emitting nucleus can be identified and its activity quantified by means of $\alpha$-ray spectrometry due to its unique $\alpha$-particle energy signature. The emission of $\alpha$ particles by an ensemble of the same nuclei may be statistically distributed. For example, in the $\alpha$ decay of ${ }^{238} \mathrm{U}$ the emitted $\alpha$ particles have $\varepsilon_{\alpha 1}=4.198 \mathrm{MeV}\left(\eta_{\alpha 1}=0.77\right)$ and $\varepsilon_{\alpha 2}=4.151 \mathrm{MeV}$ $\left(\eta_{\alpha 2}=0.23\right)$, see Eq. [4] (6).

In $\beta$ decay, $\mathrm{n}$ transforms into $\mathrm{p}$ and vice versa, depending on the position of a radionuclide relative to the valley of stability (3). There is a good reason for using the names $\beta^{+}$ and $\beta^{-}$particles for $\mathrm{e}^{+}$and $\mathrm{e}^{-}$created in $\beta$ decay, since this clarifies their origin and explains their high energy (which is still generally lower than that of $\alpha$ particles). The spectrum of $\beta$ radiation is, in contrast to that of $\alpha$ radiation, continuous in energy, since some of the energy is taken by $v_{\mathrm{e}}$ or $\overline{v_{\mathrm{e}}}$. A $\beta$-emitting radionuclide is usually characterised by the average and maximum energies of the emitted $\beta$ particles, the former being roughly $1 / 3$ of the latter (7). Therefore, one must take into account this in Eq. [4] with regard to $\varepsilon_{\beta j}$. The statistical branching of emission energies is present in $\beta$ decay as well. For instance, ${ }^{137} \mathrm{Cs}$ emits two types of $\beta$ particles when transmuting, with the average energies of $156.8 \mathrm{keV}\left(\eta_{\beta 1}=0.946\right)$ and $415.2 \mathrm{keV}\left(\eta_{\beta 2}=0.054\right)$. Some radionuclides undergo both $\alpha$ and $\beta$ decay; for instance, naturally occurring ${ }^{212} \mathrm{Bi}$ exhibits an $\alpha$ decay into ${ }^{208} \mathrm{Tl}$ in $36 \%$ of the cases, and a $\beta$ decay into ${ }^{212} \mathrm{Po}$ in $64 \%$.

Due to the quantisation of nuclear energy levels, $\gamma$ photons have well defined energies, and this is the basis of $\gamma$-ray spectrometry, which is the most potent experimental method in radioecology, able to identify radionuclides and quantify their $A$ more efficiently than $\alpha$-ray spectrometry. The number and statistical distribution of $\gamma$ emissions vary from nucleus to nucleus. For instance, there is no $\gamma$ emission that accompanies the transmutation of ${ }^{90} \mathrm{Sr}$ into ${ }^{90} \mathrm{Y}$, whereas when ${ }^{137} \mathrm{Cs}$ transmutes to metastable ${ }^{137} \mathrm{Ba}$, there are four gamma emissions with $31.82 \mathrm{keV} \leq \varepsilon_{\gamma m} \leq 661.62 \mathrm{keV}$ and $0.0022 \leq \eta_{\gamma m} \leq 0.8462$. There are also very complex situations, such as those in the decay of ${ }^{214} \mathrm{Bi}$, where the number of emissions is close to two hundred, with 76.86 $\mathrm{keV} \leq \varepsilon_{\gamma m} \leq 3269.7 \mathrm{keV}$ and $9.8 \times 10^{-5} \leq \eta_{\gamma m} \leq 0.4609$.

Besides "classical" $\alpha$ and $\beta$ decays, there are also other nuclear processes that result in radiation emission. A transmutation similar to $\beta^{+}$decay is electron capture, where a $\mathrm{p}$ in a nucleus captures an $\mathrm{e}^{-}$from the atomic shell, transforms into an $\mathrm{n}$ and emits a $v_{\mathrm{e}}$, which may also result in the emission of $\gamma$ photons until the lowest energy level of the nucleus is reached. In some processes, $\mathrm{p}$ or $\mathrm{n}$ are emitted from a nucleus, and in spontaneous or induced fission, smaller nuclei (fission fragments) are emitted together with $\mathrm{p}$ and $\mathrm{n}$. There are also radiation emissions that change neither $Y$ nor $Z$. These are termed internal conversion and isomeric transition. Isomeric transition is similar to the regular emission of a $\gamma$ photon. The only difference is in the time scale involved: while a $\gamma$ photon is normally emitted due to the relaxation of a nucleus from an excited state that lasts about one picosecond, in isomeric transition the metastable state lasts longer than a nanosecond. In internal conversion, the relaxation of a nucleus from an excited state does not cause $\gamma$ photon emission, but an ejection of an $\mathrm{e}^{-}$from the atomic shell.

Nuclear processes which result in the emission of radiation are summarised in Table 1 . They are known from nuclear physics, whereas radioecology and radiotoxicity

Table 1 Modes of nuclear radiation emission

\begin{tabular}{|c|c|c|}
\hline Mode & Emitted radiation & $\begin{array}{c}\text { Daughter } \\
\text { nucleus }\end{array}$ \\
\hline$\alpha$ decay & $\alpha$ & $Y-4, Z-2$ \\
\hline $\mathrm{p}$ emission & $\mathrm{p}$ & $Y-1, Z-1$ \\
\hline $\mathrm{n}$ emission & $\mathrm{n}$ & $Y-1, Z$ \\
\hline double $\mathrm{p}$ emission & $2 p$ & $Y-2, Z-2$ \\
\hline $\begin{array}{l}\text { spontaneous } \\
\text { fission }\end{array}$ & $\begin{array}{c}\text { smaller nuclei and } \\
\text { nucleons }\end{array}$ & \\
\hline induced fission & $\begin{array}{c}\text { smaller nuclei and } \\
\text { nucleons }\end{array}$ & \\
\hline$\beta$ decay & $\mathrm{e}^{-}$and $\bar{v}_{e}^{-}$ & $Y, Z+1$ \\
\hline$\beta^{+}$decay & $\mathrm{e}^{+}$and $v_{e}$ & $Y, Z-1$ \\
\hline electron capture & $v_{e}$ & $Y, Z-1$ \\
\hline double $\beta$ - decay & $2 \mathrm{e}^{-}$and $2 v_{e}^{-}$ & $Y, Z+2$ \\
\hline double $\beta^{+}$decay & $2 \mathrm{e}^{+}$and $2 v_{e}$ & $Y, Z-2$ \\
\hline $\begin{array}{l}\text { double electron } \\
\text { capture }\end{array}$ & $2 v_{e}$ & $Y, Z-2$ \\
\hline $\begin{array}{l}\text { isomeric } \\
\text { transition }\end{array}$ & $\gamma$ & $Y, Z$ \\
\hline $\begin{array}{l}\text { internal } \\
\text { conversion }\end{array}$ & $\begin{array}{l}\text { e- from atomic } \\
\text { shell }\end{array}$ & $Y, Z$ \\
\hline
\end{tabular}

$Y$ and $Z$ refer to the mass number and charge of the mother nucleus. All of the listed modes may result in an additional emission of $\gamma$ photons 
address the impact of this radiation on the environment and organic matter.

\section{Interactions of nuclear radiation and matter}

Several types of highly energetic radiation may be emitted due to nuclear processes, which may result in the ionisation of atoms and molecules, if matter is exposed to such radiation. The most abundant products of radioactive decay are $\alpha, \beta$, and $\gamma$ rays, and they interact with matter differently. The effects of $\alpha$ and $\beta$ particles are similar, because they are charged and interact with electrical charge along their paths via the long-range EMF. As they are passing through matter, they lose energy, as described by the Bethe formula, which states that the loss of energy per travelled distance is proportional to the square of the charge of a particle (8). This energy is transferred to atoms and molecules of the exposed material, causing ionisation. However, the charge of $\alpha$ particles is +2 , whereas that of $\beta$ particles is -1 or +1 , which means that $\alpha$ particles interact with matter stronger and lose energy faster than $\beta$ particles. Because $\alpha$ particles are heavy, their trajectories are straight and their stopping distance in a given material is a function of energy only. By contrast, $\beta$ particles change direction as they collide with atoms and molecules, which results in a wiggly path and a variable stopping length. Alpha particles deposit more energy into matter than $\beta$ particles because of their larger energies, and their stopping distance is shorter. The energy of $\alpha$ particles is between 4 and $9 \mathrm{MeV}$, and in water they stop after $30-150 \mu \mathrm{m}$. The same intervals for $\beta$ particles are typically $0.15-3.5 \mathrm{MeV}$ and $0.03-1.7 \mathrm{~cm}$, respectively (9).

Since $\gamma$ rays consist of photons, that is, of massless quanta of electromagnetic radiation, they interact with matter differently, via three mechanisms. The first is Compton scattering, i.e., the inelastic scattering of a highenergy photon on an electron. This results in the ionisation of an atom or a molecule, while the photon loses energy but continues to propagate after the scattering. The second mechanism is photoelectric effect, in which a photon is completely absorbed, and this also causes ionisation. The third mechanism is the production of $\mathrm{e}^{-}-\mathrm{e}^{+}$pairs in the vicinity of a heavy nucleus. In this process, a photon with a minimum energy of $1.022 \mathrm{MeV}$ is converted into an $\mathrm{e}^{-}-\mathrm{e}^{+}$ pair. Since antimatter is not stable, the $\mathrm{e}^{+}$soon annihilates with an $\mathrm{e}^{-}$, which results in the creation of two photons with an energy of $511 \mathrm{keV}$ each. They have exactly this energy, because it corresponds to the mass of $\mathrm{e}^{-}$and $\mathrm{e}^{+}$, which is required by the mass-energy equivalence and the law of conservation of energy. These photons can afterwards cause more ionisations. Generally, the penetration of $\gamma$ radiation into matter is much stronger than that of $\alpha$ and $\beta$ radiation.

Interactions of $v_{\mathrm{e}}$ and $\overline{\mathrm{e}}_{\mathrm{e}}$ with matter are marginal, but this is not the case with protons and neutrons which may also be emitted in nuclear processes. Just like $\alpha$ and $\beta$ particles, protons interact with matter mainly due to its charge and the long-ranged EMF. Their interactions with nuclei via the short-ranged SNF are much less frequent. Therefore, protons behave in a way similar to $\alpha$ and $\beta$ particles. Neutrons are, however, electrically neutral and can therefore interact only via the SNF or the magnetic component of the EMF (which is a weak interaction that cannot cause ionisation). By consequence, neutrons travel long distances through matter. However, when they interact with a tissue, the health consequences may be significant.

\section{RADIONUCLIDES IN THE ENVIRONMENT}

Radioecology is a scientific discipline which addresses the presence and propagation of radionuclides in natural and agricultural systems populated by humans, animals, and plants. It studies the impact of environmental radioactivity on living organisms at the level of populations and communities and also uses radionuclides as markers in studies of different ecological processes (10). Radioecology rests on interdisciplinary research of the distribution and ecological impact of radionuclides in the environment. The distribution of a radionuclide in the environment is determined by its chemical properties which are set by valence electrons. Its ecological impact depends on the radiation emission, which is a nuclear property.

\section{Naturally occurring radionuclides in the environment}

Numerous radionuclides have been identified so far, of which at least 3000 have been characterised experimentally (3). However, a large percentage of them are of no interest to radioecology, since they either decay rapidly or are not present in the environment in considerable quantities (unless there has been a leakage from a facility where they have been produced, used, or stored). Generally, radionuclides can be naturally occurring or anthropogenic.

There are numerous naturally occurring radionuclides, and many of them originate from primordial radionuclides which have been formed in massive stars. All primordial radionuclides have very long half-lives, the shortest being 704 million years of ${ }^{235} \mathrm{U}$ and the longest $2.41 \times 10^{24}$ years of ${ }^{128} \mathrm{Te}$. Four of them are very important in radioecology: ${ }^{40} \mathrm{~K}\left(T_{1 / 2}=1.25 \times 10^{9}\right.$ years $),{ }^{235} \mathrm{U},{ }^{238} \mathrm{U}\left(T_{1 / 2}=4.47 \times 10^{9}\right.$ years $)$, and ${ }^{232} \mathrm{Th}\left(T_{1 / 2}=1.40 \times 10^{10}\right.$ years $)$. Of these, ${ }^{40} \mathrm{~K}$ is of special importance for biological systems, as it accounts for $0.012 \%$ of all potassium, which is abundant in all living organisms. This means that the activity of $1 \mathrm{~g}$ of $\mathrm{K}$ is about $31 \mathrm{~Bq}(11)$, and it is a constant internal source of radioactivity in humans and biota. ${ }^{235} \mathrm{U}$ and ${ }^{238} \mathrm{U}$ also have fixed isotopic abundances, $0.72 \%$ and $99.275 \%$, respectively. ${ }^{232} \mathrm{Th},{ }^{238} \mathrm{U}$, and ${ }^{235} \mathrm{U}$ are parent radionuclides of their respective decay chains. These chains comprise 12-15 radionuclides and end with stable isotopes of lead. Elevated concentrations of the chain members in a tissue can be harmful not only because of ionising radiation emission but also because of the chemical toxicity of heavy metals. In addition, the chains comprise 
some radium isotopes that have a twofold negative effect on living organisms. They emit $\alpha$ particles, which makes them rather dangerous in internal exposure, and they transmute into isotopes of radon, a noble radioactive gas that can easily enter a body by inhalation.

A special class of naturally occurring radionuclides are cosmogenic radionuclides. Most of them are produced in the atmosphere, in collisions of cosmic rays with the nuclei of atmospheric gasses (12), and some even in the lithosphere (13), which is termed cosmogenic nucleosynthesis. They are relatively light elements with short to moderate halflives, and they descend towards Earth as part of aerosols and/or precipitation. For organic matter the most important is ${ }^{14} \mathrm{C}$ which, like ${ }^{40} \mathrm{~K}$, acts as an omnipresent source of radioactivity in living organisms. Other radionuclides of that kind can be used to study solar activity, which affects the flux of cosmic rays and consequently cosmogenic nucleosynthesis. These radionuclides are $\gamma$ emitters such as ${ }^{7} \mathrm{Be}$ and $\beta$ emitters such as ${ }^{39} \mathrm{Ar},{ }^{32} \mathrm{P},{ }^{33} \mathrm{P},{ }^{35} \mathrm{~S}$, and ${ }^{10} \mathrm{Be}(14-17)$. Although cosmic rays consist of very energetic particles, their flux at the Earth's surface is very weak, and this radiation poses no threat for living organisms.

Organisms on Earth have evolved in a moderately radioactive environment and have developed mechanisms to cope with radioactivity up to a certain dose. However, technological processes may result in enhanced concentrations of naturally occurring radionuclides, which then may become as dangerous as any other source of ionising radiation. This may happen in industrial processes where materials from nature, always containing a certain amount of radionuclides, are used. Good examples are oil industry (18) and the production of soil amendments for use in modern agriculture (19), but these industries are regularly monitored for radioactivity. In other words, naturally occurring radionuclides pose no threat unless their concentrations increase to abnormal levels over long periods of time. The main danger comes from anthropogenic radionuclides, which are normally not present in the environment.

\section{Anthropogenic radionuclides in the environment}

The most important source of anthropogenic radionuclides is the fission of uranium in power plants, nuclear-powered ships, and nuclear weapons tests. Some, on the other hand, are produced in controlled reactions under laboratory conditions, for instance in particle accelerators. The fission of uranium results in numerous radionuclides. Some are heavy and long-lived, such as ${ }^{239} \mathrm{Pu},{ }^{240} \mathrm{Pu},{ }^{241} \mathrm{Pu}$, and ${ }^{241} \mathrm{Am}$. The $Y$ of most of the others is between 80 and 100 or between 130 and 150, with their half-lives ranging from a few days to several tens of years.

The threat due to the presence of a radionuclide in the environment is determined by its abundance, role in living organisms, and pathways of propagation through different media. By these criteria, the most dangerous of anthropogenic radionuclides are the uranium fission products ${ }^{90} \mathrm{Sr}(\beta$ emitter, $T_{1 / 2}=28.9$ years), ${ }^{131} \mathrm{I}$ ( $\beta$ and $\gamma$ emitter, $T_{1 / 2}=8.03$ days), ${ }^{134} \mathrm{Cs}$ ( $\beta$ and $\gamma$ emitter, $T_{1 / 2}=2.06$ years, and ${ }^{137} \mathrm{Cs}(\beta$ and $\gamma$ emitter, $T_{1 / 2}=30.2$ years). They are all produced in large quantities, can enter living organisms easily by ingestion and inhalation, and can mimic some biogenic elements. ${ }^{90} \mathrm{Sr}$ can substitute calcium, ${ }^{131}$ I non-radioactive iodine, and ${ }^{134} \mathrm{Cs}$ and ${ }^{137} \mathrm{Cs}$ potassium. In addition, the presence of ${ }^{134} \mathrm{Cs}$ is a clear indicator of a nuclear accident, since this radionuclide is not produced in nuclear explosions. Although the half-life of ${ }^{131} \mathrm{I}$ is short, it poses a threat because it does not substitute another atom (like $\mathrm{Sr}$ substitutes $\mathrm{Ca}$ ) but directly takes the role of non-radioactive iodine. Moreover, carried by air masses, it can travel long distances before decaying [for instance, its presence was measured in Zagreb, Croatia, after the Fukushima accident (14)]. Both ${ }^{90} \mathrm{Sr}$ and ${ }^{137} \mathrm{Cs}$ have long half-lives, and this is the reason why they are of special interest in radioecological studies. Although the main releases of ${ }^{137} \mathrm{Cs}$ and ${ }^{90} \mathrm{Sr}$ occurred relatively long time ago, during nuclear weapon tests and the Chernobyl disaster, these dangerous radionuclides are still abundant in the upper atmosphere from whence they descend towards the surface and enter the ground-level environment.

Besides their generally negative ecological impact, anthropogenic radionuclides may also have a positive role. They can be used in different technological processes, as well as in medical diagnostic and therapeutic procedures. For example, ${ }^{60} \mathrm{Co}$ and ${ }^{137} \mathrm{Cs}$ are used in gamma-ray radiography for cargo scanning. ${ }^{131} \mathrm{I}$ is widely used in medical procedures related to thyroid gland. ${ }^{60} \mathrm{Co},{ }^{137} \mathrm{Cs}$, ${ }^{198} \mathrm{Au},{ }^{192} \mathrm{Ir},{ }^{125} \mathrm{I}$, and ${ }^{103} \mathrm{Pd}$ are used in brachytherapy (20). ${ }^{60} \mathrm{Co}$ is usually the source of radiation for the gamma knife. ${ }^{99 \mathrm{~m}} \mathrm{Tc},{ }^{123} \mathrm{I},{ }^{111} \mathrm{In},{ }^{201} \mathrm{Tl}$, and ${ }^{67} \mathrm{Ga}$ are used in single-photon emission tomography, while positron emission tomography is based on the use of ${ }^{18} \mathrm{~F},{ }^{11} \mathrm{C},{ }^{15} \mathrm{O},{ }^{13} \mathrm{~N}$, and ${ }^{64} \mathrm{Cu}(21)$. Medical and technological procedures employing radioactive sources continue to develop.

Once used, radioactive matter must be disposed in a safe and ecologically harmless way, and there is much concern about that. This is, however, a social and legal problem, not a technological one. The long-term disposal of fission products has been technologically solved, and the major threat lies in misuses of regulations and standards, which may range from simple negligence to criminal activities leading to unauthorised dissemination of radioactive matter. Radiopharmaceuticals must be very active and they therefore decay rapidly, so there are no problems with their long-term storage. They might become a threat only if they are not safely transported from production facilities to medical institutions or if the safety procedures during application are not implemented to the letter. In other words, we have developed technology for the safe handling of radioactive matter, and radioecological concerns should address mishandling and misuse of the existing regulations and procedures. 


\section{EFFECTS OF IONISING RADIATION ON LIVING ORGANISMS}

\section{Qualitative considerations}

According to a 1963 definition by the International Atomic Energy Agency (IAEA), the toxicity of a radionuclide is "...the ability of the nuclide to produce injury, by virtue of its emitted radiation, when incorporated in a body" (22). This early definition of radiotoxicity took into account only the hazard due to a radionuclide being inside a body. Nowadays, however, the study of damage caused by ionising radiation is no longer limited to internal sources, but includes external sources such as nuclear radiation, X-rays, and even UV radiation, all of which have lately been on the rise. It therefore seems more appropriate to use the terms radiotoxicity and radiotoxicology in a wider sense that encompasses internal and external sources and every radiation that may cause ionisation in organic matter. However, one still cannot regard radiation from a source inside a body on par with radiation coming from the outside. Skin, for example, is effective in stopping $\alpha$ and $\beta$ radiation, and external irradiation by $\alpha$ and $\beta$ particles over skin is considered less threatening, even though $\beta$ particles may cause radiation burns. By contrast, $\alpha$ particles from internal sources are extremely dangerous, as there is no skin to stop their strong interactions with tissue and the consequent deposition of large amounts of energy.

Ionising radiation has enough energy to break chemical bonds and alter chemical properties of atoms and molecules, which in living organisms leads to changes in local biological mechanisms. The local deposition of energy is the main cause of irreparable tissue damage, whereas the same energy absorbed over a larger volume causes milder effects that can be repaired. This also sheds more light on the fact that $\alpha$ particles cause more damage than $\beta$ or $\gamma$ radiation, since their stopping distance is short and the deposition of energy very local. In contrast, $\beta$ particles and $\gamma$ (or X) photons scatter several times during their travel through a tissue and cause ionisation over a larger volume. The time of exposure has a similar effect: the absorption of a given radiation dose is more dangerous if the exposure time is short, since biological repair mechanisms are more effective over long time. For instance, to absorb about $10 \mathrm{~Sv}$ over a few hours can be lethal, whereas this equivalent dose absorbed over a lifetime is usually harmless.

In order to induce noticeable effects in a living organisms, ionisation by high-energy particles and photons must alter the functioning of a large number of cells and/ or their ability to divide. This, of course, involves complicated processes, but two of these can be singled out for their dominant effects. The first is direct ionisation of DNA, and the second is ionisation of water molecules (which are the most abundant in a cell) and other organic molecules (23). The latter mechanism affects the DNA indirectly as well, and this is why the overall consequences of exposure to ionising radiation are mainly related to DNA damages $(23,24)$. These damages can be reparable and irreparable, may cause mutations and chromosomal aberrations, lead to cell death or mitotic inhibition, etc. Of course, this may have severe consequences, such as radiation sickness or cancer, but also helps in oncologic radiotherapy and related procedures. Cells which divide faster are more sensitive to the described processes, and this means that different tissues respond to ionising radiation differently.

Radiotoxicological relevance of a radionuclide depends on its abundance and $T_{1 / 2}$, chemical properties that determine the pathways of its propagation through the environment and uptake by living organisms, type and energy of the radiation it emits, possible chemical toxicity alongside radiotoxicity, and, finally, on its biological half-life $T_{\text {bio }}$ in a human body (25). The effects of $T_{1 / 2}$ and $T_{\text {bio }}$ are combined into an effective time $T_{\text {eff }}$ according to

$1 / T_{\text {eff }}=1 / T_{\text {bio }}+1 / T_{1 / 2}$

which is characteristic of a given radionuclide not only because of $T_{1 / 2}$ but also because $T_{\text {bio }}$ depends on its chemical and metabolic properties. The values of $T_{1 / 2}, T_{\text {bio }}$, and $T_{\text {eff }}$ of selected radionuclides are listed in Table 2.

We shall first address naturally occurring radionuclides. Since ${ }^{40} \mathrm{~K}$ is a biogenic radionuclide we have evolved with, and since its presence in the body is controlled by physiological processes, it is not considered to be a threat in internal exposure. However, its concentration may be elevated in certain industrial products, e.g., in fertilisers (19), which increases the risk of external exposure to its $\gamma$ radiation. The same holds for all $\gamma$ emitters within the ${ }^{238} \mathrm{U}$, ${ }^{235} \mathrm{U}$, and ${ }^{232} \mathrm{Th}$ decay chains. Some members of these chains pose more threat than others. These are, first of all, isotopes of Ra and Rn, most notably those with the longest $T_{1 / 2}$, that is, ${ }^{226} \mathrm{Ra}\left(T_{1 / 2}=1600\right.$ years) and ${ }^{222} \mathrm{Rn}\left(T_{1 / 2}=3.8\right.$ days $)$ from the ${ }^{238} \mathrm{U}$ decay chain. ${ }^{226} \mathrm{Ra}$ is chemically similar to $\mathrm{Ca}$ and can substitute it both in geological formations, including soil (26), and in organic matter. Therefore, its migrations through the environment more or less follow those of $\mathrm{Ca}$,

Table 2 Characteristic times $T_{1 / 2}, T_{\text {bio }}$, and $T_{\text {eff }}$ of selected radionuclides, expressed in years (y) and days (d) (25)

\begin{tabular}{lccc}
\hline Radionuclide & $\boldsymbol{T}_{\mathbf{1} / \mathbf{2}}$ & $\boldsymbol{T}_{\text {bio }}$ & $\boldsymbol{T}_{\text {eff }}$ \\
\hline${ }^{3} \mathrm{H}$ & $12.3 \mathrm{y}$ & $12 \mathrm{~d}$ & $12 \mathrm{~d}$ \\
\hline${ }^{131} \mathrm{I}$ & $8.3 \mathrm{~d}$ & $138 \mathrm{~d}$ & $7.6 \mathrm{~d}$ \\
\hline${ }^{90} \mathrm{Sr}$ & $289 \mathrm{y}$ & $50 \mathrm{y}$ & $18.3 \mathrm{y}$ \\
\hline${ }^{137} \mathrm{Cs}$ & $30.08 \mathrm{y}$ & $70 \mathrm{~d}$ & $70 \mathrm{~d}$ \\
\hline${ }^{238} \mathrm{U} /{ }^{235} \mathrm{U}$ & $4.47 \times 10^{9} \mathrm{y}$ & $15 \mathrm{~d}$ & $15 \mathrm{~d}$ \\
\hline${ }^{226} \mathrm{Ra}$ & $1600 \mathrm{y}$ & $44 \mathrm{y}$ & $42.8 \mathrm{y}$ \\
\hline${ }^{210} \mathrm{~Pb}$ & $22.2 \mathrm{y}$ & $10 \mathrm{y}$ & $6.9 \mathrm{y}$ \\
\hline${ }^{210} \mathrm{Po}$ & $138.4 \mathrm{y}$ & $60 \mathrm{~d}$ & $41.8 \mathrm{~d}$ \\
\hline${ }^{239} \mathrm{Pu}$ & $24110 \mathrm{y}$ & $200 \mathrm{y}$ & $198.4 \mathrm{y}$ \\
\hline
\end{tabular}


which also applies to its uptake into living organisms. It tends to concentrate in the bones if ingested, has a long $T_{\text {eff }}$, transmutes through $\alpha$ decay (emitting photons in the process) directly into ${ }^{222} \mathrm{Rn}$, a noble gas and an $\alpha$ emitter that also can be inhaled. In fact, ${ }^{222} \mathrm{Rn}$ inhalation is considered to be the most serious radiological threat from naturally occurring radioactivity, with proven links to lung cancer (27). A whole cascade of radionuclides and their decays (emitting $\alpha, \beta$, and $\gamma$ radiation) follows after the decay of ${ }^{222} \mathrm{Rn}$. This eventually results in radioactive ${ }^{210} \mathrm{~Pb}$ with $T_{\text {eff }}=6.9$ years and, finally, stable ${ }^{206} \mathrm{~Pb}$, which adds the chemical toxicity of lead to its radiotoxicity due to ${ }^{222} \mathrm{Rn}$ inhalation. Because of that, serious measures have been taken over the last decades to reduce inhalation exposure to ${ }^{222} \mathrm{Rn}(28)$.

Of anthropogenic radionuclides, the most dangerous are fission products, as outlined before. Some of them are extremely toxic and can therefore be considered poisons, e.g., ${ }^{239} \mathrm{Pu}$, which is an $\alpha$ emitter with $T_{\text {eff }}=198.4$ years and which concentrates in the bones. However, heavy long-lived fission products entering a living organisms have quite limited pathways, and the majority of long-term health problems due to the radiotoxicity of anthropogenic radionuclides is caused by lighter fission products ${ }^{131} \mathrm{I},{ }^{134} \mathrm{Cs}$, ${ }^{137} \mathrm{Cs}$, and ${ }^{90} \mathrm{Sr}$ (see above). Judging by the long $T_{\text {eff }}=18.3$ years (Table 2 ), ${ }^{90} \mathrm{Sr}$ is especially dangerous although it emits only $\beta$ radiation, unlike the other three radionuclides which are both $\beta$ and $\gamma$ emitters.

\section{Quantification through physical modelling}

Physical approach to the complex effects of ionising radiation on biological systems relies on establishing a proper relation between $D$ and $H$, taking into account that, in general, different tissues interact with high-energy particles and photons differently. Exposure of an organ $\Omega$ to radiation $\Lambda$ (which can be $\alpha, \beta, \gamma, \mathrm{X}, \mathrm{n}$, etc.) results in the absorption of a dose $D_{\Omega \Lambda}$. If the organ is exposed to several types of radiation, it receives an equivalent dose

$$
H_{\Omega}=\Sigma_{\Lambda} w_{\Lambda} D_{\Omega \Lambda},
$$

where $w_{\Lambda}$ is the radiation weighting factor (29) (see Table 3). While $D_{\Omega \Lambda}$ is measured in Gy, the use of $w_{\Lambda}$ allows us to introduce $\mathrm{Sv}$ as the unit for $H_{\Omega}$. The total equivalent dose for the whole organism is calculated as follows:

$$
H=\Sigma_{\Omega} w_{\Omega} H_{\Omega},
$$

where $w_{\Omega}$ is the weighting factor accounting for the contribution of an organ $\Omega$ (29) (see Table 4) and satisfying $\Sigma_{\Omega} w_{\Omega}=1$. The unit of $H$ is also Sv.

The above considerations, supplemented with the data in Tables 3 and 4, assume that a body and/or a given organ is exposed to ionising radiation but do not specify whether exposure is internal or external. For some weakly penetrating types of radiation, such as $\alpha, \beta$, or $p$, it is implicitly assumed that the source is internal. For strongly penetrating radiation, such as $\gamma$ or $\mathrm{X}$ photons, doses from external sources received through skin are also important, and this leads to some widely used practical quantities. The first is ambient dose equivalent $H^{*}(10)$, representing $H$ at $10 \mathrm{~mm}$ below the skin for a person occupying a given volume of space. The second is personal dose equivalent $H_{\mathrm{p}}(10)$, which is calculated for a specific person taking into account the type of radiation, geometrical aspects of exposure, etc. These quantities are important because external exposure to high-energy photons is nowadays widespread. An example is the exposure of patients and medical personnel to $X$ and $\gamma$ rays in therapeutic and diagnostic medical procedures. It has become common in medicine, industry, or cargo scanning, etc., to calibrate dosimeters to $H^{*}(10)$ rather than to $D$.

The IAEA publishes updates on numerous aspects of exposure to ionising radiation (30), and these comprehensive data are then modelled to assess the related health hazard. While modelling may change from case to case, the general approach is basically the same as that outlined above.

Table 3 Radiation weighting factors $w_{\Lambda}$ as functions of energy and radiation type $\Lambda$

\begin{tabular}{lcc}
\hline $\boldsymbol{\Lambda}$ & Energy & $\boldsymbol{w}_{\boldsymbol{\Lambda}}$ \\
\hline$\gamma$ & all & 1 \\
\hline \multirow{3}{*}{$\beta, \beta^{+}$} & all & 1 \\
\cline { 2 - 3 } & $<10 \mathrm{keV}$ & 5 \\
\hline & $10-100 \mathrm{keV}$ & 10 \\
\cline { 2 - 3 } $\mathrm{n}$ & $100 \mathrm{keV}-2 \mathrm{MeV}$ & 20 \\
\cline { 2 - 3 } & $2-20 \mathrm{MeV}$ & 10 \\
\hline $\mathrm{p}$ & $>20 \mathrm{MeV}$ & 5 \\
\hline $\begin{array}{l}\alpha, \text { fission } \\
\text { fragments, heavy } \\
\text { nuclei }\end{array}$ & all & 2 \\
\hline
\end{tabular}

Table 4 Radiation weighting factors $w_{\Omega}$ for different organs $\Omega$

\begin{tabular}{llc}
\hline $\boldsymbol{\Omega}$ & $\boldsymbol{w}_{\boldsymbol{\Omega}}$ & $\boldsymbol{\Sigma} \boldsymbol{w}_{\boldsymbol{\Omega}}$ \\
\hline $\begin{array}{l}\text { bone marrow, large } \\
\text { intestine, lungs, stomach, } \\
\text { breasts }\end{array}$ & 0.12 & 0.6 \\
\hline gonads & 0.08 & 0.08 \\
\hline $\begin{array}{l}\text { bladder, esophagus, liver, } \\
\text { thyroid }\end{array}$ & 0.04 & 0.16 \\
\hline $\begin{array}{l}\text { bone surface, brain, } \\
\text { salivary gland, skin }\end{array}$ & 0.01 & 0.04 \\
\hline $\begin{array}{l}\text { adrenal gland, thoracic } \\
\text { vertebrae, gallbladder, } \\
\text { heart, kidneys, lymph } \\
\text { nodes, muscles, oral } \\
\text { mucosa, pancreas, prostate, } \\
\begin{array}{l}\text { small intestine, spleen, } \\
\text { thymus, uterus }\end{array}\end{array}$ & & \\
\hline \begin{tabular}{l} 
total \\
\hline
\end{tabular} & & 0.12 \\
\hline
\end{tabular}




\section{Radiation doses, deterministic and stochastic effects, linear no-threshold model}

Life on Earth has evolved in a moderately radioactive environment. This suggests that low doses of ionising radiation do not pose a major health hazard. However, high doses may result in stochastic or deterministic effects on human health. Stochastic effects refer to health problems that occur by chance, because exposure to ionising radiation entails a higher probability for the development of a disease. A good example is cancer induction. Deterministic effects are those that are related to exposure beyond any doubt. Generally, there is a threshold dose for the deterministic occurrence of a disease; for instance, skin burns or bone marrow depression occur at an acute exposure to about $1 \mathrm{~Sv}$ (31). These effects also depend on the dynamics of exposure: receiving a dose over a short time, for instance during therapy, differs from prolonged exposure to an elevated level of radioactivity. In acute whole-body exposure to $\gamma$ radiation in excess of $2 \mathrm{~Sv}$ the deterministic effect is radiation sickness. If exposure is over $20 \mathrm{~Sv}$ the deterministic effect is death (31).

Since it is impossible to completely avoid exposure to ionising radiation, the IAEA provides reference levels for cumulative doses that should not be exceeded. According to these recommendations, the annual dose received through public exposure should not exceed $1 \mathrm{mSv}$. For occupational or therapeutic exposure this limit is 1 to $20 \mathrm{mSv}$, and for public exposure in emergency situations 20 to $100 \mathrm{mSv}$ (32).

There is a finer division of these limits, but there is also an intriguing, more general question: is there a dose threshold below which exposure to ionising radiation can be considered harmless or even beneficial for human health? This issue has been controversial for several decades already, and it underlies an ongoing debate on the nature of stochastic effects. It is widely accepted that adverse health effects of ionising radiation correlate linearly to exposure dose (33), as shown in Figure 1, but this has been evidenced only for doses exceeding a few tens of $\mathrm{mSv}$ (regimes II and III in Figure 1). At relatively high doses, above 100-200 mSv, adverse health effects have been well documented (regime III) whereas for lower doses, (still above 10-50 mSv; regime II), the level of confidence is not as high as for regime III. The most intriguing case is that of very low doses (regime I), especially because it is relevant to public and occupational exposure.

The working hypothesis of the IAEA is that any nonzero dose implies a non-zero risk of stochastic effects (30). This is called the linear no-threshold model (LNTM), and in Figure 1 it is marked by the dotted curve 2 in region I. While the IAEA generally supports this hypothesis, it is still reluctant to claim that it has been proven. In the scientific community, arguments have been presented both in favour (33) and against (34) the LNTM. Curves 1, 3, and 4 in Figure 1 show other possibilities for low exposure doses, and imply that the high-dose linear behaviour does not apply for low doses, because the adverse health effects could be either stronger (curve 1) or weaker (curve 3) than predicted by the LNTM. The most intriguing is curve 4, where health effects might either be absent or even positive, as indicated by the arrows. It is likely that the interest in exposure to very low doses will continue, and answering the outlined questions will require not only medical studies but also precise measurements and modelling of doses which is again in the domain of physics.

\section{CONCLUSIONS}

Radioecology and radiotoxicology are scientific disciplines that tackle the complex impacts of ionising radiation on the environment, human health, and society. Radioecological studies are mainly dedicated to identifying and quantifying radionuclides in the environment as well as to determining their sources and pathways of propagation. This information is then used to evaluate the threats coming from environmental radioactivity in a given area. Radiotoxicology is focused on identifying and assessing the effects of ionising radiation on humans and biota irrespective of the source, which can be either naturally occurring or anthropogenic. It is obvious that the two disciplines must involve scientists from different fields, that is, from various natural, technical, biotechnical, and medical sciences. However, the common basis of radioecology and radiotoxicology is physics, since most processes and interactions related to ionising radiation are in its domain.

Among all sciences, physics is specific by its methodology of using a complex mathematical language to set up models that are used to describe natural phenomena and quantify their manifestations and consequences, and it

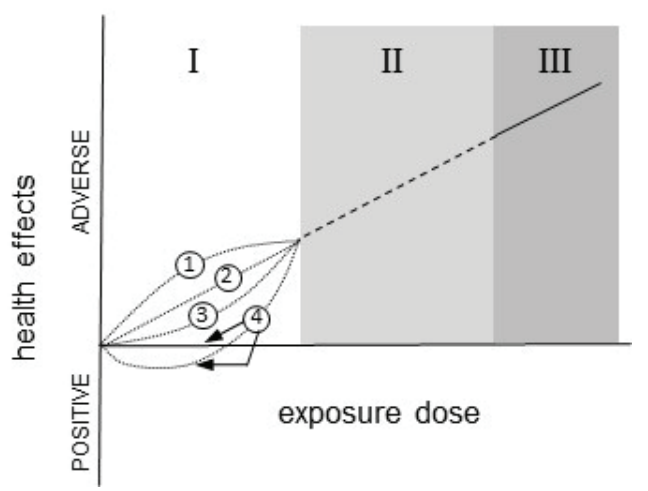

Figure 1 Health effects of ionising radiation as a function of exposure dose. The dose that corresponds to the border between regimes I and II is $10-50 \mathrm{mSv}$, and that between regimes II and III is $100-200 \mathrm{mSv}$. In regime III, adverse health effects have been well documented, while in regime II, they have been mainly identified. There is no consensus on the effects in regime I, and any of the cases 1-4 is possible. In case 1, low doses are even more harmful than the extrapolated high-dose effects represented by linear no-threshold model (case 2), whereas the opposite is argued for cases 3 and 4 . Case 4 predicts positive or no effects below a certain threshold exposure dose, as indicated by the arrows 
is generally difficult for non-physicists to understand physical concepts. However, the laws of physics can be brought closer to a wider audience if presented in a way that is scientifically correct but does not go into unnecessary detail. In this review, we have followed this approach and summarised physical phenomena relevant to researchers in radioecology and radiotoxicology without in-depth discussions and complex mathematics, as we believe that non-physicists who are active in radioecology and radiotoxicology may benefit from this simplification of a generally complex matter.

\section{REFERENCES}

1. Becquerel H. [Sur les radiations émises par phosphorescence, in French]. Comptes Rendus Acad Sci 1896;122:501-3.

2. Feynman RP, Leighton RB, Sands M. Six Easy Pieces: Essentials of Physics Explained by Its Most Brilliant Teacher. New York: Basic Books; 2011

3. Magill J, Dreher R, Sóti Zs. Karlsruher Nuklidkarte / Chart of the Nuclides. $10^{\text {th }}$ ed. Karlsruhe: Nucleonica $\mathrm{GmbH} ; 2018$.

4. Cetnar J. General solution of Bateman equations for nuclear transmutations. Ann Nucl Energy 2006;33:640-5. doi: 10.1016/j.anucene.2006.02.004

5. Wong SSM. Introductory Nuclear Physics. $2^{\text {nd }}$ ed. Weinheim: Wiley-VCH Verlag Gmbl I \& Co. KGaA; 2004.

6. Rytz A. Recommended energy and intensity values of alpha particles from radioactive decay. At Data Nucl Data Tables 1991;47:205-39. doi: 10.1016/0092-640X(91)90002-L

7. Magill J, Galy J. Radioactivity Radionuclides Radiation. Berlin, Heidelberg: Springer-Verlag; 2005. doi: 10.1007/ b138236

8. Sigmund P. Particle Penetration and Radiation Effects General Aspects and Stopping of Swift Point Charges. Berlin, Heidelberg: Springer-Verlag; 2006. doi: 10.1007/3-54031718-X

9. Cherry SR, Sorenson J, Phelps ME. Physics in Nuclear Medicine. $4^{\text {th }}$ ed. Philadelphia: Saunders; 2012.

10. Van der Stricht, Etienne, Kirchmann R, editors. Radioecology: Radioactivity and Ecosystems. Liege, Fortemps: Union Internationale de Radioécologie; 2001.

11. Samat SB, Green S, Beddoe AH. The ${ }^{40} \mathrm{~K}$ activity of one gram of potassium. Phys Med Biol 1997;42:407-13. doi: 10.1088/0031-9155/43/5/027

12. Papastefanou C. Radioactive aerosols. In: Papastefanou C, editor. Radioactivity in the environment. Vol. 12. Amsterdam: Elsevier; 2008. p. 11-58.

13. Gosse JC, Phillips FM. Terrestrial in situ cosmogenic nuclides: theory and application. Quat Sci Rev 2001;20:1475560. doi: 10.1016/S0277-3791(00)00171-2

14. Babić D, Senčar J, Petrinec B, Marović G, Bituh T, Skoko B. Fine structure of the absorbed dose rate monitored in Zagreb, Croatia, in the period 1985-2011. J Environ Radioact 2013;118:75-9. doi: 10.1016/j.jenvrad.2012.11.012

15. Babić D, Senčar J. Periodic behaviour in ground-level environmental radioactivity: fingerprints of solar activity? Proc R Soc A 2018;474:20180109. doi: 10.1098/ rspa.2018.0109

16. Usoskin IG. A history of solar activity over millennia. Living Rev Sol Phys 2017;14:3. doi: 10.1007/s41116-017-0006-9
17. McCracken KG, Beer J, McDonald FB. A five-year variability in the modulation of the galactic cosmic radiation over epochs of low solar activity. Geophys Res Lett 2002;29:14-1-4. doi: 10.1029/2002GL015786

18. Bakr WF. Assessment of the radiological impact of oil refining industry. J Environ Radioact 2010;101: 237-43. doi: 10.1016/j.jenvrad.2009.11.005

19. Saueia CH, Mazzilli BP. Distribution of natural radionuclides in the production and use of phosphate fertilizers in Brazil. J Environ Radioact 2006;89:229-39. doi: 10.1016/j. jenvrad.2006.05.009

20. Podgorsak EB, editor. Radiation Oncology Physics: A Handbook for Teachers and Students. Vienna: International Atomic Energy Agency; 2005.

21. Mattos DMM, Gomes ML, Freitas RS, Moreno S, Lima-Filho GL, Paula EF, Jales RLC, Bernardo-Filho M. Which are the most used radionuclides in the pet and in the spect techniques in the world? J Labelled Comp Radiopharm 2001;44(Suppl 1):S841-3. doi: $10.1002 / \mathrm{jlcr} .25804401295$

22. International Atomic Energy Agency (IAEA). A Basic Toxicity Classification of Radionuclides: Report of Joint Study of a Group of Consultants to the International Atomic Energy Agency. Vienna: IAEA; 1963.

23. Desouky O, Ding N, Zhou G. Targeted and non-targeted effects of ionizing radiation. J Radiat Res Appl Sci 2015;8:247-54. doi: 10.1016/j.jrras.2015.03.003

24. Lomax ME, Folkes LK, O'Neill P. Biological consequences of radiation-induced DNA damage: relevance to radiotherapy. Clin Oncol 2013;25:578-85. doi: 10.1016/j.clon.2013.06.007

25. Tuszynski JA, Dixon JM. Biomedical Applications for Introductory Physics. New York: Wiley; 2002.

26. Šoštarić M. Radiološka svojstva tla u Republci Hrvatskoj [Radiological properties of soil in the Republic of Croatia, in Croatian]. [PhD thesis]. Zagreb: Faculty of Science, University of Zagreb.

27. Darby S, Hill D, Auvinen A, Barros-Dios JM, Baysson H, Bochicchio F, Deo H, Falk R, Forastiere F, Hakama M, Heid I, Kreienbrock L, Kreuzer M, Lagarde F, Mäkeläinen I, Muirhead C, Oberaigner W, Pershagen G, Ruano-Ravina A, Ruosteenoja E, Schaffrath Rosario A, Tirmarche M, Tomášek L, Whitley E, Wichmann H-E, Doll R. Radon in homes and risk of lung cancer: collaborative analysis of individual data from European case-control studies. BMJ 2005;330:223. doi: 10.1136/bmj.38308.477650.63

28. Larsson LS. Risk-reduction strategies to expand radon care planning with vulnerable groups. Public Health Nurs 2014;31:526-36. doi: 10.1111/phn.12111

29. International Commission on Radiological Protection (ICRP). The 2007 recommendations of the International Commission on Radiological Protection. Ann ICRP 2007;37:1-332. doi: 10.1016/j.icrp.2006.06.001

30. International Atomic Energy Agency (IAEA). Radiation Protection and Safety of Radiation Sources: International Basic Safety Standards, General Safety Requirements. Vienna: IAEA; 2014.

31. Mettler FA. Medical effects and risks of exposure to ionising radiation. J Radiol Prot 2012;32:N9-13. doi: 10.1088/09524746/32/1/N9

32. International Atomic Energy Agency (IAEA). Radiation Protection of the Public and the Environment, General Safety Guide. Vienna: IAEA; 2018. 
33. Brenner DJ, Doll R, Goodhead DT, Hall EJ, Land CE, Little JB, Lubin JH, Preston DL, Preston RJ, Puskin JS, Ron E, Sachs RK, Samet JM, Setlow RB, Zaidern M. Cancer risks attributable to low doses of ionizing radiation: Assessing what we really know. Proc Natl Acad SciUSA2003;100:137616. doi: $10.1073 /$ pnas. 2235592100
34. Tubiana M, Feinendegen LE, Yang C, Kaminski JM. The linear no-threshold relationship is inconsistent with radiation biologic and experimental data. Radiology 2009;251:13-22. doi: 10.1148/radiol.2511080671

\section{Uloga fizike u radioekologiji i radiotoksikologiji}

U radu je dan pregled fizikalnih koncepata važnih za radioekologiju i radiotoksikologiju radi premošćivanja procjepa koji postoji između nefizičara u tim znanstvenim disciplinama i općenito kompliciranoga jezika fizike. Koristeći se deskriptivnim pristupom, uz samo onoliko matematike koliko je nužno, prezentirana je relevantna fizika, od fundamentalnih prirodnih sila do primjena fizikalnoga modeliranja u fenomenološkim studijama. Najprije je objašnjeno zašto su neke atomske jezgre nestabilne pa stoga transmutiraju, te koje su sile, čestice i zakoni očuvanja pritom uključeni. Potom se adresiraju interakcije ionizirajućega zračenja s materijom, što je temelj i radioekologije i radiotoksikologije. Prezentirani su relevantni prirodno pojavni i antropogeni radionuklidi te su razmatrana njihova svojstva u vezi s njihovom pojavnošću u okolišu te s toksičnošću za ljude i biotu. Pritom postoje kombinirani učinci fizikalnih i bioloških poluvremena života radionuklida, što valja uzeti u obzir pri svakoj radioekološkoj ili radiotoksikološkoj procjeni. Također je dan pregled osnova fizikalnoga modeliranja koje se uobičajeno koriste u studijama zdravstvenih učinaka izloženosti ionizirajućemu zračenju, što je primjenjivo na sve izvore zračenja, ali uz korištenje statističkih težinskih faktora koji ovise o vrsti zračenja i izloženom tkivu. Razmatrane su i tipične doze izloženosti za stohastičke i determinističke zdravstvene učinke, kao i kontraverze vezane uz hipotezu o linearnom odzivu bez praga pri vrlo niskim dozama.

KLJUČNE RIJEČI: ekologija; ionizirajuće zračenje; radionuklidi; toksičnost 